\title{
PARTIES AND THE \\ NEW POLITICAL LOGIC IN \\ NEW CALEDONIA
}

\section{Alaine Chanter}

\section{Introduction}

New Caledonia has more than 50 years' experience with party politics yet finds itself today in a situation of party fragmentation that some consider disconcertingly similar to that of neighbouring states with far less experience in party politics and Western political institutions. The reason for this disarray is, at first blush, paradoxical. The two main political groupings that either coalesced or were forged around the issue of independence are now being destabilised by this very issue, at a time when both claim success in relation to it. The anti-independence Rassemblement pour la Calédonie dans la République (RPCR) and the pro-independence coalition Front de Liberation National Kanak et Socialiste (FLNKS) both argue that the 1998 Noumea Accord - brokered between them by the French State - set in train processes conducive to the realisation of their vision for the future political status of New Caledonia. The RPCR seeks to maintain New Caledonia in the French Republic while the FLNKS has long argued for New Caledonian independence. The agreement indeed offers both possibilities. It progressively transfers political powers to a New Caledonian government but stops short of complete sovereignty pending one or more referenda on independence to be held between 2013 and 2018. The RPCR's wager is that greatly increased autonomy will undercut the impetus for independence, while the FLNKS considers that a positive experience of autonomy will render the next step of full independence relatively uncontroversial. Meanwhile, electoral support for both groups has slumped, suggesting the difficulty of selling these interpretations. Doing well is the relatively new and more centrist anti-independence party, L'Avenir Ensemble, as well as the more radical pro-independence 
Partie le Liberation Kanak (Palika). These successes tell us something of the shifting ideological landscape in New Caledonia. They also reveal how party and movement structures are increasingly unable to negotiate in a context where new issues have come to the fore while the question of independence is once again on hold. Doumenge's observations on the late 1970s, that a fragmentation of politics resulted from 'the incapacity of traditional formations to deal with the problems of the moment', might well hold true today. ${ }^{1}$ The reasons for this incapacity, and the consequent emergence of new political forces, are discussed in this chapter.

\section{The Matignon Accords}

The Noumea Accord is not the first compromise agreement between the RPCR, the FLNKS and the French State. In 1988, the Matignon Accords were signed on the heels of several years of insurrectionary activity between pro- and anti-independence militants that culminated in the Ouvéa crisis, in which four gendarmes and 19 Kanaks were killed. The scale of this violence shocked all communities in the French territory and precipitated crisis talks between the FLNKS, the RPCR and the newly elected French Socialist Government under Prime Minister Michel Rocard. The agreement to emerge out of these talks committed all parties to peaceful coexistence while the French State engaged in a 10-year program of economic development, particularly in the relatively undeveloped rural regions of the north and the Loyalty Islands, where the population is primarily Melanesian. This strategy, coined a 'rebalancing' of development, acknowledged the far greater affluence of Noumea and its surrounding municipalities, where most Europeans live, compared with that of the rest of the territory. The differential development plan was attractive to FLNKS negotiators because it proposed strategies to pump prime investment in Kanak regions, ${ }^{2}$ and was accompanied by new political structures, in particular the dividing of the territory into three provinces - those of the South, North and Loyalty Islands - which would ensure that Kanaks would have a significant measure of political and economic control over the regions where they dominated. Also crucial to their acceptance by FLNKS negotiators was the promise of a referendum on independence in 10 years. Demands for a referendum had been a key pillar of the FLNKS' political strategy during the 1980s, bolstered by the reinsertion of New Caledonia on the UN's list of territories to be decolonised. At this time, the FLNKS demanded an immediate referendum on independence. To the surprise of many, a delay of 10 years was agreed to 'with the understanding that it would enable a peaceful ten-year transition to a successful vote for independence. ${ }^{3}$ A key to this calculation was the agreement that the electoral roll for voting in a referendum would be limited to those who were resident in the territory in 1988, and their voting-age descendants. This acknowledged an important factor in electoral politics in New Caledonia: although a majority of Melanesians supported independence, Melanesians had become a minority in the territory in the $1960 \mathrm{~s}^{4}$ as a result of migration by metropolitan French and other Pacific Islanders, attracted by an economic boom in the territory brought on by strong world demand for nickel. New Caledonia has the world's third-largest deposits of nickel and it is its major export. Restricting the electoral roll would limit the political impact of 
further migration to the territory and shift the electoral demographics in favour of independence due to the higher birth rate among Melanesians. The decision to agree to a referendum in 10 years was therefore a strategic response to the reality that an immediate referendum would have resulted in a majority vote against independence.

In spite of this formula, the Matignon Accords met with considerable hostility among Kanaks, many of whom viewed them as a sell-out of the hard-won political impetus gained from years of insurrectionary struggle. A year after the signing of the accords by FLNKS leader Jean-Marie Tjibaou, he and his deputy, Yeiwene Yeiwene, were assassinated by a militant Kanak. For its part, the anti-independence community was less than enamoured by the inclusion of a prospective referendum, evident in the fact that 67 per cent of voters in Noumea rejected acceptance of the accord. ${ }^{5}$

Much effort went into 'selling' the accord to RPCR and FLNKS constituencies, a process that was actively engaged in by the local mainstream media. ${ }^{6}$ The wager was that greater economic development for Kanak communities would reduce demands for independence and produce more moderate Kanak leaders who were concerned with issues of economic development rather than independence. ${ }^{7}$

Despite French promises during the Matignon years to pursue strategies to restrict the electoral roll, as well as to promote local employment and encourage repatriation of metropolitan French public servants, ${ }^{8}$ the proportion of Melanesians in the population continued to decrease in relation to other communities, with the prospect for success in a referendum becoming ever more diminished. ${ }^{9}$ By the mid-1990s, the prospect of an imminent referendum was thrown further into doubt. RPCR leader, Jacques Lafleur, had, in 1991, called for a postponement of the referendum for 30 years to allow the territory to attain a level of economic development and political self-sufficiency that would enable a proper decision on its political future. ${ }^{10}$ Although initially rejected by the FLNKS, it was not long before FLNKS President, François Burck, himself began to publicly broach the prospect of another prolongation of a referendum. ${ }^{11}$ A major reason why the FLNKS entertained such a prospect was that a vote, were it to happen, would invariably result in a majority vote against independence. Despite the FLNKS' earlier calculation that a period of demonstrating responsible economic management would show that the Kanak community was ready to assume full responsibility, the antiindependence community had not been persuaded. Pushing the issue to a vote would only further divide and polarise the community and result in the possibility of renewed violence and political turmoil. By the mid-1990s, therefore, the major political parties had agreed to a deferment of the referendum and instead accepted a negotiated settlement, which would culminate in a vote on independence, this time in 15 to 20 years. ${ }^{12}$

Alban Bensa and Eric Wittersheim write that in the immediate aftermath of the signing of the Noumea Accord there was general relief that a new pact would bring the promise of 15 to 20 more years of relative peace. But this first reaction was also paradoxical, in that it was based on quite different convictions about the possible outcome of the process. Anti-independence groups were generally pleased with the apparent softening of pro-independence demands during the Matignon decade. They envisaged a further cooption of the Kanak political bourgeoisie with an outcome of independence in associa- 
tion with France - a state of considerably devolved autonomy but without complete sovereignty. ${ }^{13}$ This softening was evident in defections from the FLNKS, particularly to the centrist Fédération des Comités de Co-ordination des Indépendantistes (FCCI), established by once radical advocates for independence, and the alignment of the FCCI with the RPCR in a 'spirit of dialogue'. It was also apparent in the agreement of the FLNKS to countenance a further prolongation of a referendum on independence. On the other hand, pro-independence groups thought 'that the road towards independence [was] finally open'. ${ }^{14}$

This chapter argues that, on current reckoning, the anti-independence scenario is most likely to eventuate, a fact reflected in writers now describing the current state of affairs as one of decolonisation without any necessary prospect of independence. ${ }^{15}$ For this to be a scenario acceptable to hitherto advocates of independence, there would need to be the prospect of a genuine sharing of political power in the country between Kanak and loyalist political parties. There would have to be, in other words, a situation of considerably devolved autonomy in which all the major political groupings could demonstrate an active and influential involvement in determinate political processes. It is for this reason that the Noumea Accord established a collegial form of government elected by proportional representation. The intention was that, within this structure, there would emerge a multi-party Cabinet ${ }^{16}$ to ensure genuine power-sharing. Until very recently, RPCR domination of New Caledonian politics has made a mockery of this notion of collegiality, and has led pro-independence leaders to describe the accord as being 'hijacked' by the RPCR. ${ }^{17}$ Bensa and Wittersheim query whether the new institutional structures 'allow the different communities to together build a nation'. ${ }^{18}$ The major stumbling block to this outcome is the entrenched adversarial position of the RPCR, as well as its custom of manipulating the levers of power through its dominant personalities and their grip on the New Caledonian political economy. Ironically, while the Matignon and Noumea Accords bear the imprint of RPCR demands, albeit in compromise form, they establish expectations for a more consensual political culture to which the RPCR is ill equipped to respond. History might not always be destiny, but in the case of the RPCR it is a powerful factor in signalling the limits of RPCR capabilities.

\section{The RPCR in historical, sociological and political context}

Local politics in New Caledonia has always been enacted in the context of a strong French State that has maintained control over political and economic activity in the territory until very recently. ${ }^{19}$ This notion of control needs some explanation. In New Caledonia as elsewhere in the colonial world, control over local activity was largely vested in the Governor of the colony, and later the High Commissioner, but also in a local comprador class that has acquired considerable wealth and influence throughout the more than 150 years of French presence. This class has existed as the political bastion of French power, but it has also had its squabbles with France. Indeed, early politics in the colony was characterised by strident disagreements between local settlers who railed against the power of the Governor and sought the establishment of democratic institutions, including a free press, to counter this power, which was often exercised arbitrarily. ${ }^{20}$ 
Moreover, as local settlers developed the economy, some became wealthy and found themselves in competition with metropolitan economic interests in the colony. This was particularly the case with the local mine owners, who today are among the richest families in New Caledonia - the so-called 50 families $^{21}$ — and who from the outset complained about the French company Le Nickel's domination of nickel mining and smelting. While this comprador class generally understood that its dominance was secured by its relationship with France, disagreements were often expressed through demands for France to lessen its hold over local politics and the economy. They became translated in the post-war period into calls for greater political autonomy. ${ }^{22}$

This at times ambivalent attitude towards France and the exercise of colonial power was also manifest in the waxing and waning of relationships between French and local political parties and movements. Early settlers looked to political processes and institutions in metropolitan France to guide their demands for greater political freedoms from France but, as Dornoy observed, conservative politicians have generally 'always resented the influence of metropolitan parties'. ${ }^{23}$ This resentment was part of the colonial experience of subordination, as well as recognition of the increasing cultural and sociological differences that characterised New Caledonia from France. The view expressed by prominent conservative politician Pierre Frogier in 1977, ${ }^{24}$ that metropolitan parties 'did not suit the mentality of Caledonians', ${ }^{25}$ has dogged the relationship until this day. The formation of the RPCR in 1978 out of existing fractured conservative parties might have occurred at the behest of then Mayor of Paris Jacques Chirac during a visit to the territory, but it was also very much a local initiative to unite disparate conservative parties in the face of a formidable enemy - the official call by Melanesian politicians for independence.

Relationships between metropolitan political parties and local politics might be described as somewhat opportunistic. During World War II, when the first political parties were being conceived in New Caledonia, the local settler population rallied behind De Gaulle's Free France movement and the colony became an important staging post for the US's Pacific campaign. The strength of Gaullist influence was evident in postwar politics, with De Gaulle consolidating ties with New Caledonian conservatives when he visited the territory in $1956 .{ }^{26}$ As a result, local elections in 1958 witnessed the emergence of a new conservative political force, the Rassemblement Calédonien, headed by wealthy mine owner Henri Lafleur, which won 11 of 30 seats in the Territorial Assembly. ${ }^{27}$ A year later, Lafleur was elected to the French Senate and supported the metropolitan push to withdraw political powers from New Caledonia. By the late 1960s, however, the Rassemblement Calédonien had changed its tune, turning against De Gaulle to seek greater autonomy. ${ }^{28}$ Even the creation in 1977 of a local version of the metropolitan French Rassemblement pour la Republique (RPR) and its decision to go into alliance with other conservative groups reflected an ambivalence 'necessary to keep New Caledonia within France while retaining its personality. ${ }^{29}$

Dornoy is correct when she writes that the main aim of conservative politics in New Caledonia has been to conserve, ${ }^{30}$ although she might add that what is being conserved is the relative privilege of the wealthy, along with a perception of relative privilege among others, such as non-French migrants and resettled metropolitan French (Metros), who 
view greater autonomy or independence as threatening their prospects in the society. What is at play in this notion of conservation is a complex and ever shifting analysis of benefit and loss from the range of factors that impinge on local politics and the economy. These include: changing metropolitan French policies toward New Caledonia and their relative support from metropolitan political parties; the strength of local agitation for change to the status quo by oppositional groups (in later years, the pro-independence movement); and internal rivalries within the comprador class, which have often led to a fracturing of conservative political energies.

There is also the reality of considerable class and ethnic difference within the conservative movement. While the European community is in general aware of its relative privilege, when compared with most Kanaks, there are great and palpable disparities in levels of wealth, status and class within the European community. New Caledonia is unusual for having a white urban proletariat that is largely working class and works for wealthy European-owned businesses, some of which are owned by locals. ${ }^{31}$ It also has relatively poor rural Europeans - known as broussards - who work the land on holdings that are small compared with those of wealthy absentee landlords. Broussards 'have felt marginalized socially, economically, and politically by the RPCR's Noumean bias. $^{32}$ There is always therefore the possibility of dissatisfaction and a need to keep this tension under wraps. This has generally been facilitated by the fact that these poor Europeans are often reliant on patronage from wealthy businessmen for their livelihoods.

The formation of the RPCR in the year that Kanaks called officially for independence meant that the party's aim was always primarily to oppose the increasingly strident moves made by pro-independence Kanaks, many of which took the Territory to the brink of civil war, particularly in the period from 1984 to 1988. Before the RPCR's formation, the dominant political party in the territory was the Union Calédonien (UC), which, since the time of its formation in 1951, had advocated for greater autonomy for the territory. ${ }^{33}$ The UC's slogan, 'two colours, one people', expressed its pluri-ethnic emphasis and its incorporation of Kanak demands for greater political recognition and social justice. By the mid-1970s, however, ferment in the UC over the question of whether autonomy was sufficient for the realisation of Kanak aspirations, and the ultimate call by the UC for a pluri-ethnic independence, led to a break-up of the party and a mass exodus of Europeans, who eschewed the prospect of independence. Most aligned themselves with the RPCR.

From 1978 to 2004, Jacques Lafleur was president of the RPCR and New Caledonia's Deputy in the French National Assembly. Lafleur is a member of one of New Caledonia's ' 50 families', the members of whom

not only live affluently but also hold key positions in the territory's economy and administration, as well as important posts in the RPCR, forming a plutocracy of considerable influence. They are popularly perceived as having traditionally held a monopoly on New Caledonia’s socio-economic power. ${ }^{34}$

As the main political grouping advocating the maintenance of New Caledonia in the French Republic, the RPCR has garnered about 40 to 50 per cent of the total vote in 
territorial elections until $1989,{ }^{35}$ with the majority of its support in Noumea and the surrounding municipalities. ${ }^{36}$ Its support base is dominated by Caledonians of European descent and more recently arrived Metros, but it has also been the party most adhered to by the range of migrant communities in the territory, including Wallisians and Futunians, Polynesians, Indonesians, Vietnamese and ni-Vanuatu, who have felt threatened by the prospect of a Kanak socialist independence. The RPCR also draws sizeable Melanesian support. For example, in the 1989 provincial elections, the RPCR gained 33.9 per cent of the overall vote in the Loyalty Islands, ${ }^{37}$ and a small number of Melanesians have gained considerable influence in the party. This composition enables the RPCR to claim the status of multiracial or 'pluri-ethnic' party — indeed, the bearer of the UC's legacy of 'two colours, one people'.

As mentioned earlier, the European constituency incorporates a wide range of occupational and class groupings. This has been a source of friction within the party at various times. In particular, the Noumea focus of the party has led to considerable resentment from broussards who have been at the front-line of rural insurrectionary activity and have felt abandoned by the party at various moments. ${ }^{38}$ Infamous spats have occurred between party members. For example, when RPCR member of the Territorial Congress Justin Guillemard spoke out about broussard feelings of personal insecurity, describing RPCR leaders as 'Noumean racketeers', he was expelled for his outburst. ${ }^{39}$ Guillemard maintained the rage, describing the Matignon Accords as sharing 'out political and economic power between the politico-racketeers on the one hand, and the terrorist assassins on the other hand, supposedly for ten years, a time lapse that will allow you to carry out some good and juicy deals. ${ }^{40}$ Resentment of the RPCR has also fermented in Noumea, particularly among small business owners who 'at times harbor resentment about the RPCR leaders' control of Noumea's economy', and from the urban proletariat who find their job options at times circumscribed by their divergence from the RPCR line. ${ }^{41}$ These sociological and politico-economic factors behind RPCR malaise have been exacerbated by some RPCR decisions, in particular Lafleur's signing of the Matignon Accords.

Voting statistics provide an indication of levels of support for RPCR policies. In addition, the occasional public dispute between RPCR members delineates fault lines in its constituency. But generally, the internal workings of the party remain secret, and this might be explained by the relatively undemocratic nature of a party that has relied on internal patronage for party mobility. This contrasts quite significantly with the modus operandi of most pro-independence parties, which have generally held annual congresses where decisions are taken by majority vote, if not consensus. It is difficult to know therefore what the policy debates are within the RPCR, or the extent to which policy options are discussed openly within it. There is evidence that Lafleur had to work hard to steer his party towards acceptance of the Matignon Accords. ${ }^{42}$ Later dissent within the RPCR after Lafleur's signing of the Noumea Accord crystallised around claims of a lack of democracy within the party and the inordinate power of Lafleur (see section on centrist politics below). There are strong reasons to believe that these have been central characteristics of party operations for a very long time. 
Disagreement within the RPCR has precipitated the establishment of more rightwing loyalist pressure groups and parties, in particular the Front Calédonien (FC) and the New Caledonian chapter of the Front National (FN[NC]). The FC, formed in 1982, primarily gathered together disaffected broussards, and French migrants from other French colonies, such as Algerian pieds-noirs. Its members were more likely to initiate direct action in pursuit of its loyalist objectives. Infamously, the FC organised a 'picnic' in the southern town of Thio in 1985, resulting in armed clashes with FLNKS militants and considerable publicity for the party, even in metropolitan France. ${ }^{43}$ The FC lost its only two seats in the 1989 provincial elections, gaining only 4.1 per cent of the vote in the south, the only region where it stood candidates. ${ }^{44}$ The FC's vote appears to have transferred largely to the $\mathrm{FN}(\mathrm{NC})$, which has increased its electoral strength considerably since its formation in 1984 . The FN(NC) is a subsidiary of the metropolitan Front National and reports directly to it. The intimacy of this relationship was experienced early in the party's history when metropolitan FN leader, Jean-Marie Le Pen, circulated a letter questioning the presence of a Melanesian, François Neoere, at the head of the party, forcing his resignation in early 1986. ${ }^{45}$ The Front National's appeal in New Caledonia is its consistent and strident refusal to engage in negotiations about the question of independence, a stance that obviously makes it distinct from the RPCR. The FN(NC) described the Matignon Accords as an abdication to the 'murderous folly of the FLNKS', 46 and called for the abrogation of the accords after the high 'no' vote in the referendum in the greater Noumea region. A reduction in its number of seats in the 1989 provincial elections led McCallum to suggest that the $\mathrm{FN}(\mathrm{NC})$ 's influence as a loyalist force was waning. ${ }^{47}$ In the 1999 provincial elections, however, the party regained its two lost seats in Congress, giving it a total of four, a position it retained in the 2004 provincial elections. The electoral balance in the Southern Province now affords the FN(NC) the balance of power, which it is more likely to exercise in alliance with the RPCR if required, rather than with the more reconciliatory Avenir Ensemble. ${ }^{48}$ Its influence is therefore becoming stronger and reflects the fact that a small ${ }^{49}$ but resolute proportion of the population in the south rejects countenancing any compromise over the question of independence.

Another leakage from the RPCR has been from its Wallisian constituency. Wallisians are the third-largest ethnic group in New Caledonia, comprising about 10 per cent of the population on the main island. ${ }^{50}$ The community has tended to align itself with the RPCR against calls for a Kanak socialist independence from which they fear they will be excluded. During the 1980s, the RPCR employed a small group of Wallisian bodyguards who made their presence felt at anti-independence demonstrations and engaged in street fighting with independence supporters, activities that generated much hostility towards this community from Kanaks. ${ }^{51}$ By the late 1980 s, however, Wallisians began to shift away from the RPCR. In 1989 Kalepo Muliava formed the Union Oceanien (UO), criticising the RPCR for its opportunistic attitude towards Wallisians and claiming that, under the RPCR, the Wallisian community 'hasn't advanced an inch in ten years. We are as marginalised as the Kanaks'.52 Moreover, Muliava held out an olive branch to Kanaks, acknowledging Wallisian 
'cultural cousinage with Kanaks'. 53 By 1994, a new islander party, the Rassemblement Démocratique Océanien (RDO), was formed under the leadership of Aloisio Sako. It declared support for an independent, democratic and multiracial nation. ${ }^{54}$ The RDO was accepted into the FLNKS in 1998 and Sako was elected to Congress on the FLNKS ticket in 1999 and again in 2004. ${ }^{55}$ Although most Wallisians continue to vote for the RPCR, the significance of the RDO cannot be underestimated. The results of any referendum on independence could be determined by the extent to which it is able to attract the Wallisian vote. Relations between Kanaks and Wallisians remain rocky in some communities and are getting worse in others. In late 2001, armed conflict erupted between Kanaks and Wallisians in the St Louis community in Mont-Dore near Noumea, resulting in three dead and several wounded. ${ }^{56}$ In addition, RDO President Sako expressed frustration at the slowness of assistance to Wallisian communities under the terms of the Noumea Accords, stating: 'We have contributed to the wealth of this country, we have worked hard ... Yet today most of the aid measures and re-balancing benefits Kanak not us.' 57 There are clearly sizeable obstacles in the way of the further alignment of Wallisians to the pro-independence cause.

After the 2004 RPCR election slump, Lafleur resigned from the position of president, signalling the possibility that a new political emphasis might emerge within the party. It is difficult to see, however, where the party can move, with the more reconciliatory ground now being occupied by Avenir Ensemble and the intransigent position by the $\mathrm{FN}(\mathrm{NC})$. It will maintain its symbolic status as signatory to the accords but might see its political status further wane as a result of the new logic of compromise that it introduced into the political equation in New Caledonia by the very act of signing the accords.

\section{Pro-independence political parties}

Universal suffrage came to Melanesians only in $1957,{ }^{58}$ however, a decision by the French National Assembly in 1951 had conferred voting rights on almost half of eligible Melanesians, marking the genesis of their political mobilisation within party structures. ${ }^{59}$

Until recently, the main pro-independence party in New Caledonia has been the Union Calédonien (UC), and all but one FLNKS leader has been from the UC. ${ }^{60}$ It has been widely accepted that the impetus behind the formation of the UC in the early 1950s came from the Protestant and Catholic Churches in the territory. ${ }^{61}$ More recently, work by the New Caledonian historian Ismet Kurtovich has uncovered the extent to which this agitation from the churches was itself a response to the popularity of the communist movement within Melanesian communities. This movement was the first to champion indigenous and migrant rights as central to the political project. The presence among the organising group of two Melanesian chiefs encouraged other Melanesians to identify with the sentiments expressed by this movement. Alarmed by its popularity, the churches quickly agitated to set up alternative political structures that would redirect this political impetus towards more contained ambitions. ${ }^{62}$ These efforts ultimately resulted in the official formation in 1956 of the UC, which had existed successfully since 1951 as a movement and had attained considerable electoral success, with the election of its 
leader, Maurice Lenormand, as Deputy to the French Assembly in $1951,{ }^{63}$ and by gaining a majority of seats in territorial elections in 1953, including its first Melanesian members. ${ }^{64}$ Its slogan, 'two colours, one people' and program reflected the extent to which indigenous advancement was at the core of the movement's mission, although, as Henningham notes, its style was somewhat paternalistic. ${ }^{65}$

By the mid-1950s, the UC had strengthened its social agenda and increased its following among trade unions. ${ }^{66}$ This generated deep hostility from conservative forces, which accused Lenormand of communist sympathies and of being anti-French. This criticism continued despite Lenormand campaigning for the maintenance of New Caledonia in the French Republic at the referendum of September 1958, initiated by De Gaulle in all the overseas dependencies and giving each the possibility of independence. ${ }^{67}$ A further manifesto drawn up in 1967 once again rejected independence and requested instead 'a statute of self-government to implement decolonization in New Caledonia ${ }^{68}$ - a position that seems similar to that adopted by the UC today.

Considerable radicalisation occurred among young Melanesians during the 1970s, in part as a result of the participation of some in radical student politics in France during the 1960s as well as because of the more general push for recognition of indigenous rights in international forums. This radicalisation led to severe problems for the UC, which opposed the option of independence. The first breakaway political group was the Union Multiraciale de Nouvelle-Calédonie (UMNC), which split from the UC in 1970, and which led calls for independence. It was the UMNC's leader, Yann Celene Uregei, who had returned home from an official visit to France to demand independence in the Territorial Assembly for the first time. As a result of pressures from outside and within the party, the UC Congress of 1977 adopted a position for independence. Speakers at this congress once again voiced positions that are uncannily prescient today, particularly the idea that internal self-government was the best way to move towards independence. ${ }^{69}$ Despite the mass exodus of European members, the UC has nonetheless remained the largest pro-independence party in New Caledonia, with membership from Catholic and Protestant communities spread across its regions. Henningham estimates that the UC is supported by some 55 to 60 per cent of pro-independence Kanaks, ${ }^{70}$ a number that has probably reduced as a result of the rise in popularity of Palika (discussed below). Henningham's description of the UC as 'pragmatic' and social democratic ${ }^{71}$ generally holds today. These characteristics have led the UC and the FLNKS to agree to the Matignon and Noumea Accords, decisions that, as mentioned above, have resulted in considerable alienation from the UC's constituency given the prospect of independence is once again distant.

Another more radical pro-independence party, the Union Progressiste Multiraciale (UPM), was formed in 1974 as a breakaway party of the UMNC (which became the Front Uni de Liberation Kanak [FULK] in 1977), with the main aims of land reform and the economic development of Melanesians. ${ }^{72}$ The party changed its name to the Union Progressiste Melanesien (UPM) in $1977^{73}$ and continues to the present. This party has been concerned primarily with land reform and was at the forefront of land occupations in the 1980 s. $^{74}$ Although in its early iterations it employed radical rhetoric 
and had links with the French Trotskyist Ligue Communiste Revolutionnaire, ${ }^{75}$ in more recent years it has tended to align with the UC on policy matters, putting into contention Henningham's description of the party as 'radical' and 'Marxist. ${ }^{76}$

In 1976, the Parti Socialiste Calédonien (PSC) was formed with the socialist principles of the nationalisation of territorial resources, particularly nickel mining, and the advancement of working-class interests. Importantly, the PSC did not at this time support independence, arguing that New Caledonia was too small a state to consider such an option. Instead it supported greater autonomy. ${ }^{77}$ The party shifted to supporting independence in the 1980s and is the only pro-independence party to include a predominantly European membership, most of whom are trade unionists. ${ }^{78}$ Finally, in 1976, various radical movements coalesced in the formation of the Parti de Liberation Kanak (Palika), which advocated the demise of colonialism in New Caledonia through 'revolutionary Kanak Socialist Independence'. ${ }^{79}$ Although Palika advocated revolutionary struggle to overthrow colonialism, it nonetheless participated in the 1977 territorial elections, with a significant showing in each of the electoral regions, particularly the Loyalties and the east. ${ }^{80}$ Palika argued that social reforms could be achieved via this means and that parliamentary salaries would help the party progress its platform. ${ }^{81}$

This issue of parliamentary participation has been a dilemma within pro-independence political parties. The boycotting of elections has been a key strategy in parties' armoury, yet there have also been times when they have contested elections individually or collectively as part of a united movement. The decision to forge the type of alliances that would ultimately result in the creation of the FLNKS was driven by new electoral laws initiated in the late 1970s by conservatives in the French Parliament. ${ }^{82}$ These established a minimum bar of 7.5 per cent of votes in order to gain a seat in the Territorial Assembly. ${ }^{83}$ These measures were intended to thwart participation by the smaller proindependence groups but instead precipitated their fusion in the Front Independentiste (FI) ${ }^{84}$ which successfully contested the 1979 elections, gaining 14 seats compared with the RPCR's 15, with a centrist FNSC holding the balance of power with seven seats. ${ }^{85}$

In 1981, after generally positive comments from the Socialist Party on the issue of self-determination, the FI supported the Socialist candidate, François Mitterrand, in the second round of the election. Nonetheless, the FI was suspicious of the Socialists, a view that was borne out when no strong support for independence ensued from Mitterand's victory. ${ }^{86}$ However, a generally reformist climate and the knowledge of increased support for Kanak aspirations within government in France led to pressure for political reform in New Caledonia and to the circumstances in which the FI, in alliance with the centrist FNSC, gained power, with UC leader, Jean-Marie Tjibaou, leading the Government. ${ }^{87}$ By this stage, Palika had excluded itself from the FI and therefore any chance of parliamentary participation. This followed an internal split, which resulted in the formation of a new political party based primarily in the Loyalty Islands, the Liberation Kanak Socialiste (LKS). ${ }^{88}$ Internal tensions between FI parties led to leakages in various electoral contests. ${ }^{89}$ Increasing disenchantment of pro-independence parties towards the policies of the Socialist Government, particularly the Lemoine Statute, which eschewed immediate independence in favour of greater autonomy and a referendum on independ- 
ence in 1989, produced increasing tensions, riots and direct action waged by Palika militants - in other words, considerable instability. Meanwhile, the UC drew up its own timetable for independence, which determined that a referendum in 1984 would result in independence in 1985. Importantly, this plan presupposed electoral reforms that limited voters to Kanaks and residents who had one parent born in the territory. ${ }^{90}$ The 'pragmatic' UC had for a long time known that a successful vote on independence could occur only through limiting the electoral franchise.

All these tensions came to ahead in the 1984 territorial elections, which were boycotted and obstructed by the FI (the LKS participated). The FI also withdrew all members from government institutions and planned the establishment of the provisional government of Kanaky, renaming itself the FLNKS. As Connell writes, through this radicalisation, the FI 'was coming much closer into line with the more militant and socialist Palika, which had long argued that ... independence will not fall from the sky through the good will of Mitterrand, other Pacific countries, the United Nations or the good God; it can only be achieved through the struggles of Kanaks and exploited workers. Without a struggle there will be no independence. ${ }^{91}$ The first Congress of the FLNKS was attended by all pro-independence parties (the UC, Palika, UPM, PSK, FULK), barring the LKS. Palika attended because it saw that the FLNKS had moved towards its own more radical position in support of militancy and direct action. ${ }^{92}$

In the face of this crisis, a new plan was developed by a special envoy to the territory, Edgard Pisani, which advocated the solution of independence in association with France, with a referendum in July 1985 and the possibility of independence in association on January 1, 1986. Importantly, voting would be restricted to those who had lived in the territory for at least three years. The FLNKS rejected this solution as neo-colonial, with one FLNKS leader describing it as a 'mutilated' form of independence. ${ }^{93}$ Continued insurgency resulted in the development of a new plan by the French Prime Minister, Laurent Fabius (herein after 'the Fabius Plan"), which introduced one of the key components of subsequent political compromises, the division of New Caledonia into political regions, in this case four - the North, East, South and Loyalty regions and the devolution of powers to these regions. A referendum on self-determination was proposed for 1987. This outcome was ultimately endorsed by the FLNKS at its 1985 Congress, albeit in a lukewarm manner. ${ }^{94}$ Significantly, the outcome of the elections was a victory for the FLNKS in all regions bar the South, and it was UC militants who acquired the role of President in the North, East and Loyalties. ${ }^{95}$ UC pre-eminence reflected the numerical strength of the UC vis-à-vis other pro-independence parties, but also the lead that the UC had taken in much of the militancy of 1984 and 1985. The UC has paid a disproportionate price for this militancy with the assassination of a string of leaders: first, UC Secretary-General Pierre Declercq in 1982, then UC leader Eloi Machoro in 1985, followed by Jean-Marie Tjibaou and Yeiwene Yeiwene in 1989.

The election of a conservative government in France in March 1986 produced a blocking of funds to the regions and the development of a new statute, termed the Pons Statute, which conceived of a division of the territory into four new regions, with the north divided according to an east and west axis, a division that had been long opposed 
by the FLNKS. ${ }^{96}$ An acute level of frustration at the retraction of the meagre gains constituted by the Fabius Plan led to the FLNKS boycotting the 1987 referendum and the April 1988 regional elections. ${ }^{97}$ These boycotts were, for the first time, adhered to by all pro-independence groups — the LKS had joined the FLNKS in the face of the deteriorating political circumstances. The political crisis served to focus energies on communal goals and smooth over differences. This provisional solidarity was always going to be sorely tested in less polarised political circumstances.

These indeed existed in the 1990s. As UC leader Roch Wamytan said in 1991, 'Three years ago it was easy to be cohesive in the face of the active campaign against the French; now the FLNKS needs to adjust to a new situation.'98 Internal tensions erupted after the assassination of Tjibaou and Yeiwene by a militant pro-independence Kanak. Much finger-pointing and recrimination ensued. At the same time the FLNKS had to comport itself as a relatively united and responsible signatory to the Matignon Accords, a juggling act that required much deft handling of discord. 99

Since the signing of the Matignon Accords, compromise has continued to be the Realpolitik of FLNKS policy, and this has led to further dissension among those who perceive that little of substance has been done to improve Kanak economic and political opportunities, let alone signal the possibility of independence. This has led the UC to lose electoral support in favour of the less compromised Palika. Palika's reputation as a more militant party was strengthened in the 1990s as a result of tensions in the FLNKS between UC leaders and the then FLNKS President, Palika's Paul Neoutyne, who consistently asserted demands for Kanak socialist independence in the face of equivocal comments on the issue by UC leaders. In what amounted to an acknowledgment that such comments had harmed the party, UC leader and Vice-President of the FLNKS, Roch Wamytan, said that the party would channel its energies into winning support from other pro-independence parties, rather than becoming chummy with the RPCR. ${ }^{100}$ By 1995, relations between Palika and the UC were not much better. After the Matignon Accords, senior members of the UC broke away from the party and formed the Fédération des Comités de Coordination d'Indépendence (FCCI). ${ }^{101}$ The FCCI claims to 'cut across old divisions ${ }^{102}$ in its support of the accords, but its poor showing in the 2004 provincial elections supports Connell's earlier view that they are 'perceived as having lost the support of their constituencies' and have joined 'the line awaiting Lafleur's powerful patronage'. ${ }^{103}$

Faced with the seeming obsequiousness of senior sections of the UC in the 1990s and a Kanak electorate already suspicious of the Matignon Accords, the UC's reputation as leading party of the pro-independence cause has been seriously undermined. As one Kanak commented in relation to the FLNKS, but also by implication the UC, 'Challenge and distrust in the leadership come from the grassroots level, especially young Kanak militants who have always felt betrayed by the signing of the Matignon Accords in 1988, sweeping away their dream to see a liberated Kanaky which many have died for during the armed struggle against the French establishment in the early 1980s. ${ }^{104}$

No unified FLNKS list could be agreed to in the lead up to the 1999 provincial elections with various groupings contesting the three provinces. Fragmentation was even more acute for the 2004 provincial elections, with 14 pro-independence lists in the 
Southern Province, nine in the north and eight in the Loyalty Islands. ${ }^{105}$ As a result, in the Southern Province, no list received over the 5 per cent benchmark with the result that six pro-independence seats were lost. The absence of any pro-independence voice in the Southern Province creates a de facto form of partition in New Caledonia, which is, as Maclellan notes, "in stark contrast to the spirit of partnership and "working together" that the Noumea Accords encourages'. ${ }^{106}$ Fragmentation has led to voter support for pro-independence parties ( 40 per cent) not being translated into seats in Congress (less than one-third). ${ }^{107}$

Connell asks whether the unprecedented level of discord within the FLNKS suggests that 'FLNKS actually represents nothing more than an "imagined community"'. 108 Insofar as the independence imagination is fading within it, this might indeed be the case. French Government policy has been very successful in reorienting independence energies towards more pragmatic questions of economic and social development, with the result that the rage is no longer being maintained in many FLNKS quarters. But there is a community that once belonged to the FLNKS that still imagines independence, and Palika appears to be one of its rising stars. ${ }^{109}$

Another is the militant Union Syndicalist des Travailleurs Kanak et Exploité (USTKE). The USTKE was a founding member of the FLNKS and celebrated its 20th anniversary in 2001, reaffirming its goal of building a multiracial, independent Kanaky'. ${ }^{110}$ It has been strongly critical of the Noumea Accord, in spite of being a party to its negotiations. ${ }^{111}$ It is also the sole voice to demand an immediate accession to independence on the grounds that any devolved process would result only in a country dominated by loyalists. ${ }^{112}$ Perhaps because of its radicalism, the USTKE has been very successful in the past 15 years in dominating unionism in New Caledonia. It has not been shy about using confrontational strike action, winning significant gains for workers in the process. This has further enhanced its appeal to workers of European, Melanesian and, most importantly, Wallisian ethnicities, making it a genuinely multiracial organisation. ${ }^{113}$ The USTKE's fusion of independence demands with militant unionism signals a maturation of New Caledonian civil society. It recognises that colonial patronage has not just affected the continuing political status of New Caledonia but has resulted in endemic discriminatory economic relationships. Fighting for workers' rights therefore achieves not only purely economic goals but addresses underlying political inequities. ${ }^{114}$ Its multiracialism is also considered progressive in a context where race has often been the fault-line of political divisiveness.

\section{Centrist politics}

Until recently, centrist politics have struggled to get a hold in New Caledonia. The reasons for this are in part suggested by the analysis already undertaken: Kanak demands for independence led to a polarisation of opinion and a political and ideological climate that was far from conducive to moderation. This is not to say that attempts did not occur, but the most successful of these were in the period before the eruption of widespread violence in 1984 and subsequent to the enactment of the Matignon Accords, which elevated moderation and compromise as a central dynamic of the political process. 
But there is another reason why centrist politics has had difficulty germinating. This relates to the active efforts by conservative forces in the territory to stymie moderate voices, be these political figures or the occasional forays into the media of centrist political groups. ${ }^{15}$ The vilification throughout the 1960s of UC leader Maurice Lenormand is a case in point. Despite his generally moderate views on promoting greater autonomy in the territory, and his continued insistence that New Caledonia remain part of France, he was subject to accusations of being a communist, to judicial prosecution on trumpedup charges of being responsible for a bombing at the UC newspaper's headquarters, as well as having his house burnt. ${ }^{116}$ More generally, the UC's political moderation before their 1977 call for independence received little acknowledgment, let alone affirmation, from conservative political groups.

One notable if short-lived exception was the prominence of the centrist FNSC group, which did well in the 1979 territorial elections, gaining seven seats to the RPCR's 15 and the FI's 14 , and therefore holding the balance of power. ${ }^{117}$ FNSC members had primarily been supporters of the UC in the period before its advocacy of independence. They went into coalition with the FI in 1982 out of opposition to the RPCR's inflexible response to the political demands of the $\mathrm{FI}^{\prime 118}$ - a move that served only to discredit them in the eyes of their supporters, with the result that the party collapsed in 1984 and most supporters moved to the RPCR or even to the FN(NC). The FNSC had tried to propagate more centrist views by establishing in 1981 a daily newspaper, La Presse Calédonienne, in competition with the monopoly daily, Les Nouvelles Calédoniennes, but the paper did not attract advertising revenue, largely as a result of pressure from RPCR stalwarts on potential advertisers. ${ }^{119}$ This was not the first time that such pressure tactics had been employed. Such practices are consistent with Chappell's observation that 'Less respectful critics refer to Lafleur's powerful political and economic patronage system as a "mafia". 120

The lack of success until recently of centrist political parties belies the fact that centrist positions have a long heritage in New Caledonia and are rooted in important sociological foundations. During the FNSC's tenure, a conference organised by the Socialist Government between the FI, the RPCR and the FNSC and held in France acknowledged the place of Europeans of New Caledonian heritage, arguing that their interests had often been forgotten in the polarisation around issues of independence, and referring to this group as 'victims of history'. ${ }^{121}$ These people have a long experience of living alongside Melanesians, and their lifestyles evince considerable hybridity. In addition, there is noticeable metissage within this community. They identify primarily as Caledonian before being French, and have acquired the name Caldoche in recent years. Although racism has tarnished their interactions with Melanesians, they are increasingly aware of the need for mutual accommodation. Often they are people of modest means who have difficulty identifying with the elitist politics of RPCR leaders. Their interests were initially represented by the UC, which, as discussed above, advocated pluriethnicity and championed various economic and social rights. The UC's support for political autonomy was consistent with this reformist agenda, but it was then always a form of autonomy in association with France. 
It is the historical resonance of this position that enabled the Socialist Government of François Mitterrand to propose in 1985 a compromise solution for the territory that entailed a form of independence in association with France. While the proposal was considered scandalous by pro- and anti-independence groups alike for giving away too little or too much, it in fact advocated a position that had dominated postwar politics. Doumenge notes that between 1953 and 1972, a majority of the electorate had favoured 'internal autonomy'. ${ }^{122}$ Indeed, in the 1953 election for the Territorial Assembly, the UC had advocated a form of autonomy with France retaining control only of foreign affairs, defence and finance, ${ }^{123}$ a proposal that was uncannily similar to Pisani's independence in association. The UC again pushed for a similar statute in $1967 .{ }^{124}$

There is, therefore, considerable precedence to current decolonisation policies enacted through the Matignon and Noumea Accords. Indeed, aside from the period of acute polarisation over independence, all major political persuasions have at various times called for a phased introduction of degrees of self-government in recognition of the need to establish political institutions capable of assuming new responsibilities. Thus, the UC's reversion to a more centrist position in the 1990s is not only an acknowledgment of its limited ability to continue an insurrectionary struggle, but also a reflection of genuine ideological positions held within the party, particularly by its older leaders.

In addition to this historical resonance, the political impetus towards consensus and conciliation promoted by the signing of the Matignon and Noumea Accords, as discussed above, has undermined the ability of its signatories to assert extreme positions. In the case of the FLNKS and the RPCR, the accords have largely undermined their raison d'être. This is the context in which centrist political groups have acquired prominence in the past 10 years. Their leaders in this period have been a handful of well-known personalities in New Caledonia, foremost among them the businessman and former Employers Federation head Didier Leroux. Leroux's party, Une NouvelleCalédonie Pour Tous (UNCT), formed in 1995, surprised most observers by winning seven seats in the Southern Province and two in the Northern Province in elections held that year. The UNCT's success resulted in the RPCR losing its majority in the Territorial Congress for the first time and precipitated new 'unholy' political alliances between FLNKS members and the RPCR. ${ }^{125}$ In its election publicity, the UNCT voiced positions that have come to characterise more centrist anti-independence politics. In particular, the theme of promoting peace and toleration contrasted strongly with Lafleur's well-known assertion that the path towards peace was not through concessions to the demands of the different communities in the territory but rather through maintaining the strength of the European community in the face of these demands. Rather, the UNCT considered New Caledonian 'pluralism' a positive characteristic not "synonymous with division but $\ldots$ rather the expression of democracy'. ${ }^{126}$ Elsewhere Leroux spoke of his desire for a society 'where it is good to live together, and not in a peace where the winner imposes itself on the loser. ${ }^{127}$ In a direct swipe at Lafleur, the UNCT called for more ethics in public life through avoiding 'elected representatives using their mandate in order to favour businesses in which they have interests in order to enrich themselves personally. ${ }^{128}$ At its first congress, the UNCT called for New 
Caledonia to remain linked to France through institutional, judicial and financial means, but nonetheless advocated a large degree of political autonomy similar to that afforded French Polynesia. ${ }^{129}$ By 2004, when Leroux was re-elected to Congress on the Avenir Ensemble ticket, these political premises had permutated somewhat into a 'deep conviction that Caledonia can only remain in the Republic if it is able to construct a more just and tolerant society' through reducing 'the political and social fractures that divide it'. ${ }^{130}$

Evidence that this desire was widespread came in the 2004 elections when Avenir Ensemble gained a majority of seats in the Southern Province, displacing for the first time the RPCR's majority (19 to the RPCR's 16). This resulted in Avenir Ensemble's Harold Martin replacing Jacques Lafleur as President. Martin had been one of several prominent RPCR members (including Sonia Lagarde, Marie-Noëlle Thermereau and Philippe Gomes) who had openly rebelled against Lafleur's authority in the party during the 2001 municipal elections by calling for greater democratisation and a greater adherence to the consensual spirit of the Noumea Accords. Announcing his 2004 alliance with Leroux, Martin stated that the goal of a 'common destiny' was not being pursued by the RPCR, adding, "This agreement is supposed to help us build a common destiny, whatever our political, ethnic differences are ... But it certainly doesn't look that way.' ${ }^{131}$

Martin was joined by Lagarde, Thermereau and Gomes on the Avenir Ensemble ticket, and Thermereau was ultimately elected as President of the Government of New Caledonia, signalling the demise of RPCR political authority and the emergence, as one commentator put it, of a new form of stability in which 'change has ceased to frighten'. ${ }^{132}$ When Themereau had resigned from the RPCR in 2001, she had done so denouncing Lafleur's 'impressive drift towards greater and greater personal power'. ${ }^{133}$ Her election was greeted with cheers from a packed gallery. Analogies were drawn with the fall of the Berlin Wall and comments were made that people could now express themselves freely without fear of reprisals, indicating how strong Lafleur's personal power had been. ${ }^{134}$ But Themereaux's election was not just a beginning; it also signified a fruition of changes that had been occurring during the 1990s. In the decade after the signing of the Matignon Accords, various forums broached the issue of a New Caledonian identity that was not racially delineated. Work done by scholars at the French University of the Pacific, as well as by writers and journalists, has taken impetus from the sentiments of the accords to advance a view of New Caledonian identity that dared speak in reconciliatory terms. ${ }^{135}$ Avenir Ensemble's ascendancy in part reflects this work. FLNKS leader Roch Wamytan was indeed correct when he commented that the Noumea Accord showed 'mentalities had evolved'. ${ }^{136}$ This evolution might result in a greater acknowledgment of the necessity, and perhaps the benefits, of coexistence, but it suggests the need for independence.

The extent to which the political question has now shifted away from that of independence per se to one of coexistence is evident in the changing political discourse of hitherto more radical politicians. Palika’s Déwé Gorodé was elected as Government VicePresident in the 2004 elections. In a subsequent radio interview, she interpreted the new citizenship called for in the Noumea Accord as involving Kanak acceptance of 'those who arrived in our country after us, to build the nation together'. Reflecting on the process leading up to the Noumea Accord, she added, 'It meant we had to talk with them, we 
had to work with them, and then we signed an agreement with them. We must convince each other and work together to build this country. ${ }^{\prime 37}$ Such conciliatory discourse is a far cry from the radicalism of calls for Kanak socialist independence. It suggests that proindependence politics is also working to win over the expanding middle ground. ${ }^{138}$

\section{Conclusion}

It is broadly accepted that some of New Caledonia's longstanding political structures particularly the RPCR and the FLNKS - are in disarray. These signatory parties to the Matignon and Noumea Accords bear the responsibility for reorienting politics away from acute physical confrontation towards more conciliatory processes. Perhaps ironically, however, they have both demonstrated an inability to reorient their own modus operandi towards this new political logic.

I have argued that this political atmosphere has drawn out sentiments that have always existed as undercurrents in New Caledonian society. These include acute racism, divisive French policies towards the colony, a powerful comprador class that has stymied equitable development and a period of heightened political tension precipitated by demands for independence that banished any moderation from the political lexicon for a very long time. The RPCR and the FLNKS signed up to the accords because, essentially, they had little choice given the level of insurgency and the possibility of civil war. Perhaps it is now fitting that the baton should be handed on to new, or fundamentally reworked, political forces, which can bring a fresher eye to the formidable tasks ahead. For many, this still involves achieving independence for New Caledonia. Loyalist politics have come quite a way in countenancing this possibility, just as pro-independence politics have muted the more radical calls for an independence determined by Kanaks alone. But the centrist forces emerging at the moment are unlikely to trip the wire and support independence in nine years. This will result in ever increasing numbers of disenfranchised Kanaks, and perhaps Wallisians, who cannot look to a future in which their interests come to the fore. Lest we forget the lessons of the 1960s and 1970s, this is the stuff from which radicalism is born.

\section{Footnotes}

1 Doumenge, Jean-Pierre. 1995. 'L'Enracinement des mouvements politiques en Nouvelle-Calédonie: Faits et Prospective'. Unpublished paper. p. 3.

2 The French Government is required to allocate three-quarters of its civil capital investment funds and project subsidies to the northern and Islands Provinces. High Commission of the Republic in New Caledonia. 1977. New Caledonia: The Matignon Accords, 1991 Progress Report. Noumea: Pacific Compos. p. 8.

3 Wamytan Roch cited in Connell, John. 2003. 'New Caledonia: An Infinite Pause in Decolonization?' The Round Table, Vol. 368. pp. 125-43, at p. 130.

4 Connell, John. 1987. 'New Caledonia or Kanaky? The political history of a French colony.' Pacific Research Monograph, No. 16, Canberra: National Development Studies Centre, ANU. p. 97. 
5 McCallum, Wayne. 1992. 'European Loyalist and Polynesian Political Dissent in New Caledonia: The Other Challenge to RPCR Orthodoxy.' Pacific Studies, Vol. 15, No. 3. pp. 39-40.

6 Chanter, Alaine. 2002. 'Postcolonial Politics and Colonial Media Representations in New Caledonia.' Pacific Studies, Vol. 25, No. 3. pp. 17-36, at pp. 26-7.

7 Connell, 2003, op. cit. p. 128.

8 Maclellan, Nic. 1999. 'The Noumea Accord and Decolonisation in New Caledonia.' The Journal of Pacific History, Vol. 34, No. 3. pp. 245-52, at p. 249.

9 The population of Melanesians fell from 44.8 per cent in 1988 to 44.1 per cent in 1998. Maclellan, ibid. p. 5.

10 Pacific Report, June 25, 1992.

11 Ibid.

12 Connell, 2003, op. cit. p. 130.

13 Bensa, Alban and Eric Wittersheim. 1998. 'A la recherché d'un destin commun en NouvelleCalédonie.' Le Monde Diplomatique. Available at http://www.monde-diplomatique.fr/1998/07/BENSA/10658.html,

14 Ibid.

15 Chappell, David A. 1999. 'The Noumea Accord: Decolonization Without Independence in New Caledonia?' Pacific Affairs, Vol. 72, No. 2. pp. 373-91.

16 Maclellan, Nic. 2004. 'From Eloi to Europe: Interactions with the ballot box in New Caledonia.' Unpublished paper. p. 11.

17 Ibid. p. 12.

18 Bensa and Wittersheim, op. cit.

19 Chesneaux, Jean. 1988. 'Kanak Political Culture and French Political Practice: Some Background Reflections on the New Caledonian Crisis'. In Michael Spencer, Alan Ward and John Connell (eds), New Caledonia: Essays in Nationalism and Dependency, St Lucia: Queensland University Press. pp. 56-80, at p. 68.

20 Chanter, Alaine. 1999. 'Will There Be a Morning After? The Colonial History of the Media in New Caledonia.' The Journal of Pacific History, Vol. 34, No. 1. pp. 91-108, at pp. 94-6.

21 McCallum, op. cit. p. 33.

22 Henningham, Stephen. 1992. France and the South Pacific: A Contemporary History. North Sydney: Allen \& Unwin. p. 55.

23 Dornoy, Miriam. 1984. Politics in New Caledonia. Sydney: Sydney University Press. p. 197.

24 Frogier was elected President of New Caledonia’s Government Council in 2001. Chappell, David A. 2002. 'New Caledonia — Political Review.' The Contemporary Pacific, Vol. 14, No. 2. pp. 446-55, at $448-9$.

25 Dornoy, op. cit. p. 159.

26 Connell, 1987, op. cit. p. 248.

27 Ibid. pp. 249-50.

28 Ibid. p. 254.

29 Dornoy, op. cit. p. 199.

30 Ibid. pp. 260-1.

31 Henningham, op. cit. pp. 64-5.

32 McCallum, op. cit. p. 33.

33 Henningham, op. cit. pp. 49-56; Connell, 1987, op. cit. pp. 243-8.

34 McCallum, op. cit. p. 33.

35 Ibid. pp. 29-32; Doumenge, op. cit. p. 19.

36 McCallum, op. cit. pp. 28-9.

37 Ibid. p. 56.

38 Ibid. p. 33.

39 Ibid. p. 35.

40 Ibid. p. 39.

41 Ibid. p. 38.

42 Chanter, 2002, op. cit. pp. 26-7. 
43 McCallum, op. cit. pp. 46-7.

44 Henningham, op. cit. p. 107.

45 McCallum, op. cit. p. 41.

46 Ibid. 44.

47 Ibid.

48 McCallum, ibid. pp. 43-4, notes that the FN(NC) has, on a couple of occasions, engaged in electoral alliance with the RPCR in order to maximise the loyalist vote.

49 Ibid. pp. 44-5.

50 Chappell, 2002, op. cit. p. 449.

51 Connell, 2003, op. cit. p. 135.

52 McCallum, op. cit. p. 51.

53 Ibid.

54 Maclellan, 1999, op. cit. p. 248; Chappell, 1999, op. cit. p. 380.

55 Maclellan, ibid. p. 248.

56 Chappell, 2002, op. cit. pp. 449, 455.

57 Ibid. p. 455.

58 Dornoy, op. cit. pp. 166-167.

59 Ibid. p. 160.

60 The exception is Paul Neoutyne of Palika, who was FLNKS President in the mid-1990s.

61 Henningham, op. cit. pp. 49-50.

62 Kurtovich, Ismet. 2000. 'A Communist Party in New Caledonia (1941-1948).' The Journal of Pacific History, Vol. 35, No. 2. pp. 163-79.

63 Dornoy, op. cit. p. 161.

64 Ibid. p. 164.

65 Henningham, op. cit. pp. 53-4.

66 Dornoy, op. cit. p. 165.

67 Ibid. p. 168.

68 Cited in Dornoy, Ibid. p. 170.

69 Connell, 1987, op. cit. pp. 262-8; Dornoy, op. cit. p. 177.

70 Henningham, op. cit. p. 77.

71 Ibid.

72 Connell, 1987, op. cit. pp. 262-8.

73 Dornoy, op. cit. p. 185.

74 Henningham, op. cit. p. 79.

75 Ibid.

76 Ibid.

77 Dornoy, op. cit. p. 187.

78 Ibid. p. 79.

79 Henningham, op. cit. p. 79.

80 Dornoy, op. cit. p. 249.

81 Ibid. p. 210.

82 Connell, 1987, op. cit. p. 278.

83 Ibid.

84 The FI consisted of the UC, Palika, FULK, UPM and the PSC (Connell, 1987, op cit. p. 278).

85 Ibid.

86 Connell, 1987, op. cit. pp. 286-8.

87 Ibid. pp. 299-304.

88 Ibid. p. 305.

89 Ibid. pp. 310-11.

90 Ibid. p. 311.

91 Cited in ibid. p. 316.

92 The founding parties of the FLNKS were the UC, Palika, UPM, PSK, FULK, the USTKE and the Groupe des Femmes Kanakes Exloitées en Lutte (GFKEL).

93 Hnalaine Uregei cited in Connell, 1987, op. cit. p. 339. 
94 Connell, 1987, op. cit. p. 352.

95 Henningham, op. cit. pp. 99-102.

96 Ibid. pp. 100-1.

97 Ibid. p. 102.

98 Pacific Report, November 21, 1991.

99 There were suspicions that FULK had played a role in the plan to assassinate Tjibaou and Yeiwene.

100 Pacific Report, November 22, 1993.

101 Maclellan, 1999, op. cit. p. 247.

102 Connell, 2003, op. cit. p. 132.

103 Ibid. p. 132.

104 Cited in ibid. p.133.

105 Macllellan, 2004, op. cit. p. 11.

106 Ibid.

107 Ibid.

108 Connell, 2003, op. cit. p. 140.

109 Chappell, 2002, op. cit. p. 451.

110 Ibid. p. 454.

111 Pacific Report, February 28, 1998.

112 Bensa and Wittersheim, op. cit.

113 Chappell, 1999, op. cit. p. 381.

114 Hnalaine Uregei, personal correspondence, 1994.

115 Chanter, 1999, op. cit.

116 Henningham, op. cit. pp. 59-60.

117 Connell, 1987, op. cit. p. 279.

118 McCallum, op. cit. p. 36.

119 Chanter, 1999, op. cit. p. 101.

120 Chappell, 2002, op. cit. p. 452.

121 Henningham, op. cit. pp. 74-5; Barbançon, Louis-José. 1992. Le Pays du Non-Dit. Nouméa: Offset Cinq Edition, p. 62.

122 Doumenge, op. cit. p. 1.

123 Connell, 1998, op. cit. p. 245.

124 Connell, 1987, op. cit. p. 253.

125 Pacific Report, July 31, 1995.

126 UNCT online. 1996. Available at www.UNCT@geocities.com,

127 L'Humanité online, October 26, 1996.

128 UNCT online, op. cit.

129 Pacific Report, November 1, 1996; L'Humanité online, op. cit.

130 Gouvernement de la Nouvelle-Calédonie online. 2003.

131 'Anti-independence block gain seats in New Caledonia's Congress", Pacnews online, May 10, 2004. Available at http://www.hellopacific.com/news/general/news/2004/05/10/10reg7.html

132 Ibid.

133 Ibid.

134 'Political Quakes Shake French Pacific: The End of an Era?' Oceania Flash online, June 7, 2004. Available at http://www.asiapac.org.fj/cafepacific/resources/aspac/tahiti070604.html

135 Coulon, Marc (ed.) 1996. Etre Caldoche aujourd'hui. Lifou: Ile de Lumière.

136 'Le oui l'emporte au référendum sur la Nouvelle-Calédonie.' TF1 online, November 8, 1998.

137 'Building the nation in New Caledonia — Program Three Opinion by Déwé Gorodé.' ABC online, 2004. Available at http://abc.net.au/timetotalk/english/opinion/TimeToTalkOpinion_440057.htm

138 Gorodés election means that the two highest positions in government are held by women. These were the first provincial elections in which a new law required equal representation of women and men on party tickets. The law came into effect in the French Pacific in 2000 and requires that 'On each list, the difference between the number of candidates of each sex can be no greater than one. Each list must be composed alternatively [sic] by a candidate of each sex.' Cited in Maclellan, 2004, op. cit. p. 4. 